\title{
THE STATE AID AND INTEGRATION DEBATE IN NEW ZEALAND EDUCATION, 1877 - 1998 : POLICIES, PROBLEMS AND POSSIBILITIES
}

\author{
GREGORY LEE \\ Department of Education Studies \\ University of Waikato
}

HOWARD LEE

Department of Education

University of Otago

\begin{abstract}
This paper examines a controversial piece of education legislation - the 1975 New Zealand Private Schools Conditional Integration Act - with particular reference to its origins, historical significance, and the debate it has generated. The Act's main feature is that it permitted private, church-controlled schools to integrate into the state schooling system, and to receive full government financial aid. The 1975 'Integration Act' overturned earlier legislation (the 1877 Education Act) which had excluded the possibility of state aid being granted to private schools. Dissatisfaction with the 1877 statute led church authorities, especially Roman Catholic, to petition successive governments from 1878 to secure financial relief on the grounds of ensuring equity and natural justice for their members. Lobbying continued until the early 1970s, when politicians were required to honour recent election promises to seriously contemplate integrating private schools into the state schooling system.

Contrary to politicians' expectations, the 1975 Act did not resolve the state aid dilemma 'once and for all'. Educationists and religious commentators remained divided over the respective functions of churches and the state in educational matters. The debates intensified from 1990 when conservative politicians looked more closely at reducing public expenditure, and expressed concern at the enormous financial costs incurred through integrated schooling. Over the last eight years Ministers of Education have preferred to grant more money to independent (private) schools rather than encouraging integration, although the rising popular demand for access to integrated schools (with the accompanying pressure for further funding) has not been ignored by the present government, who profess support for New Zealanders' right to exercise their schooling preferences.
\end{abstract}

\section{INTRODUCTION}

Among the large number of potential topics available for New Zealand historians of education to investigate, one that has undoubtedly proven to be more controversial and enduring than most is the nature of the relationship between church and state in New Zealand schooling. As Jim Dakin has remarked: 
The question of how much, if any, aid should be afforded by the state to private schools has been the subject of a long and often bitter debate since the passing of the [Education] Act of 1877.1

Nineteenth century governments had steadfastly maintained that the secular spirit and substance of the 1877 legislation necessarily prevented any state aid from being granted to private schools. Successive governments throughout most of the twentieth century were also reluctant to revisit the Act. ${ }^{2}$ By 1975, however, New Zealand politicians believed they had little alternative but to fully address the difficult issue of whether or not financial aid should be given by the state to church schools. On 10 October 1975 they voted in favour of introducing an especially contentious piece of legislation, the Private Schools Conditional Integration Act. ${ }^{3}$ In doing so, many politicians hoped that this statute would finally resolve what had frequently been termed 'the state aid question'.4

\section{THE CONTEXT OF THE STATE AID CONTROVERSY}

As we might have predicted, such legislative intervention did not settle the longrunning debate. With the passing of the Education Act in 1877 - which had not only ushered in a free, compulsory, and secular primary schooling system but also expressly forbidden the granting of any financial aid to existing and proposed private, church-controlled schools ${ }^{5}$ - church authorities, most notably Roman Catholic, began to complain that they had been discriminated against by a succession of governments. 6 They lobbied for state aid for their schools, on at least two grounds. First, the success of early schooling endeavours throughout the missionary (1814-circa 1877), Crown Colony (1840-1852), and the Provincial (18531876) periods owed much to the churches' involvement well in advance of expressions of interest by the state; and second, that allocating state aid to the private schooling sector was consonant with broadly defined principles of equality between, and natural justice for, all citizens. ${ }^{7}$ Nearly a century later politicians authorised the granting of the financial relief which private schooling authorities had long sought. But it was soon viewed as an unpopular policy decision in several quarters.

During the period 1877 to 1945 there were numerous attempts by private schooling authorities to convince the legislature that state financial aid to church schools was both urgently needed and seriously overdue. ${ }^{8}$ These attempts, however, were unsuccessful. For the time being, politicians refused to revisit Charles Bowen's thesis (outlined in his prefatory remarks when presenting the 1877 education legislation to Parliament), that efficient schooling could be assured only by funding a national, state-controlled, primary schooling system rather than granting money to the various denominations, each of whom would inevitably compete with one another for scarce resources, as well as pupils. ${ }^{9}$

There was firm support for this stance from the state primary school teachers' union, the New Zealand Educational Institute. Charles McKinnon, editor of National Education (the official publication of the NZEI), articulated the union's view in 1919: 
The future of the national system [of education] depends on the strength of the resistance which is offered by the Government to the encroachment of private schools on the privileges and benefits conferred on State education by the State. 10

A similar position was adopted by politicians who were anxious to avoid becoming embroiled in bitter debate over the role of churches in education provision, which they believed had been effectively resolved by their predecessors in the legislature of 1877. George Russell, Member of the House of Representatives for Riccarton, for example, was one of several politicians in the early twentieth century New Zealand Parliament willing to declare that in education, "pure secularism...[was the] only one solid and unalterable foundation." 11 To reject such a principle, he remarked prophetically, would have far-reaching and unpalatable consequences:

...if we endow or assist sectarian institutions, no matter what church or denomination they belong to, we are only paving the way for future trouble, and laying down the means by which in time to come the whole question of denominational education, as applied to our primary schools, may be brought under review. ${ }^{12}$

Labour party politicians, although elected to government in 1935 after pledging support for introducing wide-ranging education and social reforms, were keen to avoid being seen as sympathetic to the regular demands from various church authorities for state aid to be granted to private schools. They believed that their electorates were opposed to the Catholic push for state aid especially. ${ }^{13}$

At the same time, though, these politicians did not wish to be viewed publicly as being totally indifferent to the plight of private school authorities, who had seen an ideal opportunity to gradually step up their campaign for state aid. This opportunity coincided with the election of a new, liberal-minded Labour government, as well as with steady increases in primary and post-primary enrolments which became more substantial post 1944 owing to the raising of the school leaving age to 15 years. ${ }^{14}$ Nevertheless, Rex Mason, Minister of Education in Peter Fraser's Labour government (1940-1947), chose to proceed cautiously in all of his official pronouncements on private schooling. To this end, Mason reminded educators in an official publication in 1945 that because he was "charged with administering an Education Act that insists on the secular nature of the State education system", Mason was not legally required "to deal with religious issues in setting out policy." 15 But this did not prevent the Minister from suggesting that private schools had the potential to introduce a "[welcome] diversity into New Zealand education", one couched in the following terms:

It is not for me to state the future policy of private schools except to say that...[they] will make their greatest contribution to education in New Zealand not by imitation of the State schools but by developing a character of their own. ${ }^{16}$ 
Mason's final observation was that he wished "every private school to have freedom to solve its own problems in its own way". ${ }^{17}$

The NZEI, by comparison, made no secret of their opposition to private schools. Having declared in 1944 that public schools served to "unify our New Zealand democracy to a unique extent",18 the Institute sensed mounting pressure on government to grant state aid to church schools. If the government acquiesced, the effect would be to "split and divide our national community",19 they opined. Once such aid was given to one denomination then the NZEI anticipated that others would promptly request it, on the grounds of ensuring "equal and therefore equitable treatment." 20 The Institute thought state aid provision to denominational schools was inevitable:

[Given that Roman Catholics] have never ceased to demand that the State supply the finance to educate Catholic pupils in Catholic schools...can one not then forecast for a certainty that the Catholic church...will make use of its political solidarity to have the State pay in toto the whole cost of the education it gives to its children?21

Mason and his political colleagues soon discovered that the NZEI had interpreted Catholic aspirations more accurately than had any other contemporary commentator. In the opinion of prominent Catholic spokespeople, the resolution of private schooling grievances depended on the allocation of full state funding in preference to continuing to look to the Catholic community for financial support. The Catholic refusal to accept anything less than full state aid for their schools, we suggest, helped fuel the church-state debate up to the passage of the 1975 integration legislation. 22

\section{THE CATHOLIC CASE FOR STATE AID}

The first comprehensive account of Catholic grievances in post World War II New Zealand was provided by the Rev. Dr Noel Gascoigne, a Bishop and Director of Catholic Schools for the Wellington Diocese. Addressing the Labour party caucus "on the question of state aid to the private schools" on 23 September 1948, ${ }^{23}$ Gascoigne reminded Labour politicians that Mason's advocacy of "diversity" in schooling provision ${ }^{24}$ would be achieved when law-abiding taxpayers and citizens were not financially penalised for choosing to send their sons and daughters to a non state school. Claiming that "[Catholics] do not ask for privileges: we ask for equity and justice," Gascoigne proceed to argue:

[A Catholic parent] is entitled in equity to the same financial assistance from the state as is in fact being given by the state in this country, and rightly so, to the thousands of New Zealand parents who choose freely to send their children to the schools of the state. ${ }^{25}$

Despite Gascoigne's written submission, the Labour government remained unmoved by the Catholic claim that full state aid was now a matter of urgency. The National (Holland) ministry (1949-1957) who succeeded the Fraser government, for its part, viewed the situation identically. ${ }^{26}$ Catholic 
commentators responded by noting that increased enrolments in the early 1950s had created serious staffing and accommodation problems for pupils in both private and state schools throughout the nation. Such an observation led Catholic schooling authorities in September 1956 to present a petition to Parliament, through the Holy Name Society of New Zealand, urgently seeking state aid for private schools. ${ }^{27}$ But the House of Representatives' Select Committee on Education, heavily influenced by a submission from Professor Colin Bailey, Head of the Education Department at Victoria University of Wellington (who resolutely opposed the granting of state aid to these institutions on thirteen major grounds), reported in favour of retaining the status quo. 28 Bailey's "emphatic opposition to the proposition that public grants-in-aid or tax exemptions be accorded to groups or individuals in respect of non-state schools", was founded on the premise that church and state must remain separate. ${ }^{29}$ His submission stressed "the divisive influence of state aid ... [evident to] the student of world education", which militated against religious harmony and national educational reorganisation. ${ }^{30}$ The professor observed that in those countries that granted state aid to private schools (for example, England, Scotland and Holland), considerable problems were experienced regarding the determination of eligibility for aid, its limitation, and the recruitment of teachers to work in church schools. The paramount consideration, Bailey reminded the Select Committee on Education, should lie with the short and long-term political consequences of granting state aid:

Once state aid is given, it is inevitable that the "state aid issue" becomes a permanent preoccupation of governments. Both (or all political parties) must clarify their policy about the matter, and the process of doing so must inevitably drive lines of dissent through every party.... It is not in the national interest, nor of course in the interest of political parties themselves, for such dissension to develop. 31

It was this concern in particular - notably, the fear that the state schooling system would be undermined - that finally persuaded the Parliamentary Select Committee to oppose the granting of state aid to church schools. ${ }^{32}$

Predicably, Catholic lobbying for state aid did not terminate with the Select Committee. The main Catholic education interest group, the Holy Name Society, with W.S. Otto as President of its National Council, attempted to convince the Nash (1957-1960) and Holyoake (1960-1972) governments that the post-war population increase meant school age youth could not be accommodated if Catholic authorities chose to place entry restrictions on their secondary schools. ${ }^{33}$ In other words, the state schools' accommodation and staffing problems could be eased if the state was seen to cooperate with the Catholics. Full cooperation, it was suggested, would be forthcoming once Catholic authorities had an assurance that their schools were to receive financial support from government.

\section{THE CURRIE COMMISSION AND STATE AID}

Anticipating that the demand for state aid was not going to diminish, Philip Skoglund, Minister of Education in the Nash (Labour) government, instructed the Commission on Education in New Zealand in February 1960 to consider "the 
publicly controlled system of primary, post-primary, and technical education in relation to the present and future needs of the country", as well as "the question of aid by the State to private schools". ${ }^{34}$ Evidently reluctant to examine the state aid 'question', having viewed it as a political rather than an educational concern, the Commissioners' report of July 1962 concluded that,

Although the matter of state aid for private schools was given the most concentrated attention and analysis, it is an issue which the Commission believes can be decided finally only by Parliament itself ... [the ultimate resolution of this problem] is to be found rather within the realms of politics and of community attitude and belief than of pure logic or educational theory. 35

This observation led the Commissioners to recommend that "no change [should] be made in the present public policy relating to the granting of aid to private schools".36

In examining the church-state debate in New Zealand education, Professor Ian McLaren, an historian of education, has suggested that the Commission's refusal to support state aid being given to private schools did not unduly alarm Catholic spokespeople in the early 1960s. His reasoning was that Catholic authorities had begun to appreciate that state aid was more likely to be granted when they adopted "gentler tactics" in their efforts to persuade governments to acknowledge the natural justice and financial savings associated with granting state aid to church schools. ${ }^{37}$ Their strategy soon proved to be effective. Prompted by the Minister of Finance, Robert Muldoon, the Holyoake government ignored the advice of the 1962 Commission on Education and, instead, chose to offer parents some taxation relief for their children's private schooling costs. ${ }^{38}$ This financial relief was not restricted to Catholic parents, presumably because the National government also sought to assist the financially straitened governing authorities of Protestant secondary schools, who had joined forces with Catholic education interests in 1962 to form the Interdenominational Committee of Independent Schools (ICIS). ${ }^{39}$ In McLaren's opinion, this powerful alliance "significantly altered the state aid situation", in tandem with Vatican II (19621965), the Ecumenical Council called by Pope John XXIII. 40 Approaches by the ICIS to the National government for substantial grants to independent (private) schools between 1963 and 1969 were successful; subsidies for heating, lighting, school equipment, and water rates were made available in addition to subsidies for the salaries of ancillary staff. Low interest Housing Corporation loans were also secured to allow new school buildings to be erected. ${ }^{41}$

\section{NATIONAL AND LABOUR ON STATE AID}

Although there were signs of a "healthy partnership" evolving between state and private schooling interests by the early $1960 \mathrm{~s}, 42$ this was not sufficient to convince government of the wisdom of authorising full state aid to church schools. Nevertheless, the decrease in interdenominational rivalry between Catholic and Protestant schooling authorities, as part of the ecumenical movement, ${ }^{43}$ coupled with less visible sectarian bitterness throughout New Zealand society from the 
1960s, was sufficient to persuade both liberal and conservative politicians to contemplate granting further financial assistance to these schools. ${ }^{44}$ Whilst the idea of full state aid to these institutions still remained controversial, politicians from the three political parties knew that they could not afford to ignore the debate altogether. The National party, returned to office in November 1969, now had no option but to deliver on its election promise to convene a special body - a Joint Cabinet-Caucus Committee on State Aid for Independent Schools - in February 1970, to investigate the matter of state aid. The Committee's report of December 1970 concluded that state aid ought to be increased over a seven year period, but members were not willing to endorse a policy of full state aid. ${ }^{45}$

This verdict satisfied the National government. Labour, however, sought to go further. Keen to seek office in 1972, after more than 20 years as a Parliamentary opposition party, Labour boldly declared support for integrating church schools into the state schooling system. ${ }^{46}$ Their election manifesto stated unequivocally that "Independent schools that wish to integrate themselves into the state system will be assisted to do so". 47 By 1972 Norman Kirk, the Labour party leader, had become an unapologetic advocate of integration; during the 1969 general election campaign he had only favoured increasing state aid to private schools. Accordingly, the granting of full state aid had not been considered in the earlier campaign. 48

Neither policy was accepted universally within the party, however. Keith Sinclair, a New Zealand history professor and Labour candidate for the Eden electorate in 1969, had openly equated state aid provision with "subsidies for snob schools". 49 Discussing state aid with Kirk subsequently, Sinclair wrote of his leader's philosophy:

[Kirk] convinced me that Labour's policy of increasing aid to independent - mainly Catholic - primary schools was just, by saying, quite correctly, that many of them were run down, and that it was unjust that Catholic children should receive an inferior education. 50

The 1972 Labour party manifesto had also stated that, if elected to government, Labour would call a conference for the express purpose of "determining a fair and just solution" to the ongoing state aid debate. ${ }^{51}$ Phillip Amos, the newly appointed Minister of Education, adhered to this undertaking. He convened a State Aid conference in May 1973, intending to resolve the issue "once and for all". One outcome of the conference was the establishment of an Integration Working Party under A.N.V. (Ned) Dobbs' convenorship, as Director of Education. ${ }^{52}$ In December 1974 the working party recommended that the integration of private schools into the state system should finally proceed, subject to a guarantee that the private schools' "special character" be preserved.53 On 10 October 1975 this recommendation was incorporated within the Private Schools Conditional Integration Act, to take effect from August 1976. 


\section{THE 1975 'INTEGRATION ACT' AND ITS LEGACY}

Writing one year prior to the passing of the 'Integration Act', McLaren remarked that the New Zealand political and social climate was such that "to restrict aid will prove an extremely difficult task". 54 He observed that,

the New Zealand school system remains essentially a public one, and is likely to be so long as the representatives of teaching organisations and the controlling authorities maintain their present vigilance. 55

Other commentators have since argued that the 1975 legislation represented a very real threat to the public schooling system. State teachers' organisations in particular, they noted, complained that they were inadequately represented on the Integration Working Party and, consequently, were unable to express their reservations about state aid and integrated schooling. Jack Mulheron, a spokesperson for the Society for the Protection of Public Education (SPPE); Sir Roy Jack, a former National government Speaker of the House of Representatives and Member of Parliament for Rangitikei; and Ivan Snook, Professor of Education at Massey University, were three outspoken critics not only of the 1975 Act but also the process that led to its adoption. ${ }^{56}$ Snook, for example, declared that evidence exists pointing to "some funny business behind the scenes",57 whereas Jack lamented that the 1975 legislation was "full of fish hooks and broken glass" and constituted "thoroughly bad legislation". 58 Their criticisms focused primarily on the abandonment of the principle of a church-state separation which had been embedded in education legislation for nearly a century, and at the allegedly privileged position which schools under the jurisdiction of church authorities seemed to occupy after integration, compared with their public school counterparts.

The 1975 Act allowed the controlling authorities of religious denominations to operate their church schools in return for full government funding, subject to certain conditions. The ownership of these institutions was to remain in the hands of the various religious orders, who were permitted to give sectarian instruction while at the same time receiving legislative assurance that their schools' "special character" (religious philosophy) would be preserved.59 The special character of one co-educational form one to seven integrated school in Dunedin, Kavanagh College, was defined as follows:

The school is a Roman Catholic school in which the whole school community, through the general school programme and in its religious instructions and observances, exercises the right to live and teach the values of Jesus Christ. These values are as expressed in the scriptures and in the practices, worship and doctrine of the Roman Catholic Church, as determined from time to time by the Roman Catholic Bishop of the Diocese. 60

The legislation also allowed some teaching positions to be 'tagged', such that applicants were required to demonstrate "[their] willingness to and ability to take part in religious instruction appropriate to that school".61 Predictably, such a 
provision attracted criticism, mainly because teachers could be assessed in their initial appointment (and subsequently throughout their teaching career in integrated schools) against the special character clauses based upon undisclosed moral criteria. ${ }^{62}$ Especially harsh criticism has been levelled at the legal protection accorded to integrated schools, who, unlike their state counterparts, could not be closed, decapitated, amalgamated, or zoned owing to small roll numbers. ${ }^{63}$ In the early 1980s, when state school enrolments were declining, accompanied by the imminent threat of teacher redundancies and school closures, it was only to be expected that the state sector teachers' unions - the NZEI and PPTA - would feel particularly aggrieved at the government protection they saw being unjustifiably given to integrated schools. ${ }^{64}$

Little sympathy for the stance adopted by the teachers' organisations was forthcoming from Mervyn Wellington, Minister of Education in the Muldoon government (1978-1984), however. Wellington, who later noted in his ministerial memoirs that he "faced no more important and potentially explosive issue than integration", 65 made no secret of his personal empathy for the concept and practice of integration. This was largely motivated by his wish to see greater competition occurring between schools; Wellington assumed that such competition would arise automatically with integration, and would enhance school efficiency nationwide. In October 1982 the Minister stated:

I am totally determined to complete the process of integrating those schools which have declared an intention to do so - despite the often unfounded criticism levelled at the concept of integration itself. 66

The concerns outlined by the teachers' unions and those implacably opposed to full state aid and integration post 1978 were that integrated schools would compete with neighbouring schools to attract pupils; that financial support for integrated schooling would inevitably cause state schools to be grossly underfunded; and that integrated school authorities would charge fees to cover the repayments on their subsidised, low interest Housing Corporation loans. ${ }^{67}$ These grievances were aired when Mervyn Wellington announced (one month before a change of government in 1984) that not only was additional government loan money to be set aside specifically for integrated schooling but also that the completion date for bringing several Catholic school buildings up to recognised state standards was now to be deferred for three years (from 1988 until 1991). 68

\section{THE FOURTH LABOUR GOVERNMENT}

The election of the fourth Labour (Lange) government in July 1984 resulted in no immediately discernible change in policy from that adopted by the National government. Accordingly, debate about the merits and deficiencies of integrated schooling continued to be expressed publicly. Opponents pointed to the enormous financial burden imposed upon the government in supporting integration, a reality which Russell Marshall, the new Minister of Education, was quick to comprehend. ${ }^{69}$ Alert to the Catholic authorities' complaint that the compliance costs for upgrading their schools to prescribed state school standards were greater than originally expected, ${ }^{70}$ Marshall repeated the Labour party's 1984 
election manifesto statement that "Labour remains committed to the 1975 legislation". ${ }^{71}$ His decision to permit integrated schooling authorities to delay repaying their (by now) interest free government loans for 25 years, effective from August 1986, had far-reaching economic consequences for an already heavily indebted country. Marshall argued that the new policy would "solve, once and for all, the problem of the inability of the proprietors of integrated schools to fund improvements in their schools". ${ }^{72}$ But signs of further concessions to integrated schooling authorities soon encountered stern opposition. Mulheron, for example, was critical of any 'reform' that had the effect of safeguarding, let alone enhancing, the Catholic Church's asset base. He concluded:

Church proprietors accepted the responsibility for improving their schools as part of the integration agreement... The Catholic church has no greater claim on public funds for the development of its private property than any other sectional group. ${ }^{73}$

\section{INTEGRATION, FUNDING AND PARENTAL CHOICE}

Of greater concern to the government, however, was the reaction from several independent school authorities who now saw in Marshall's revised policy statement considerable financial benefits to be derived from their reconsidering integration, but which would mean dispensing with their independent status. The potential to enhance their market standing in an already competitive schooling environment underpinned their interest. It was presumed that with integration enrolments could increase, attendance dues would be reduced, facilities upgraded, staffing expanded, and their own special character retained and protected. ${ }^{74}$ Ruth Richardson, the National party's education spokesperson, applauded this stance, because it echoed her conviction that competition between schools would automatically improve the quality of the curriculum offerings and allow parents to choose the type of institution they wanted their children to attend. ${ }^{75}$ Richardson's pronouncement was timely, given that the Report of the Taskforce to Review Education Administration in April 1988 supported the notion of parental choice. The Taskforce reasoned that "choice will involve providing a wider range of options for consumers and for learning institutions" which will, in turn, ensure "greater efficiency and equity", because staff will have to be "responsive to the needs of their students and the community".76 The inference to be drawn, of course, was that staff performance in this regard had previously been lacklustre.

The notion of parental choice in schooling and its consequences, it must be noted, was not entirely unproblematic for government. Early in his term of office, Lockwood Smith, Minister of Education (1990-1996) in the Bolger ministry, reported that "The [National] government has viewed with concern the lengthening list of private [independent] schools wishing to integrate into the state system".77 Smith was aware of the huge costs involved in integration (i.e. full state funding) compared with simply restoring the 20 per cent teacher salary grant to independent schooling authorities, which has been phased out in 1990 by the Lange government. He therefore endeavoured to discourage integration applications by increasing the funding available to independent schools by some six million dollars. ${ }^{78}$ 
Smith noted in the 1991 budget statement on education that private school funding was to be increased from 5.287 to 11.528 million dollars per year, under the rubric of allocating "enhanced support". This increase in funding, however, constituted only 0.26 percent of the total government expenditure of education (4.428 billion dollars) in $1991 .{ }^{79}$ The Minister's explanation for the budget announcement was that "the grant allows independent schools to remain that way, and therefore avoids imposing the much greater cost of integration on the state".80 He had calculated that to integrate every private school into the state system would cost an additional 45 million dollars annually, because each would have to then receive the full salary grant rather than the 20 per cent grant Smith had approved. Financial considerations undoubtedly dominated the Minister's thinking.

This decision was promptly criticised by the NZEI President, Carol Parker, who complained that private schools were continuing to receive preferential treatment from government. ${ }^{81}$ The union's response was largely ignored by the government, however, because the latter was alert to the rising public demand for access to integrated schools. This was because these schools were often seen publicly to be providing high quality teaching in smaller classes (allowing for more individual attention), giving much needed instruction in moral and civic values and virtues, and assigning particular emphasis to personal discipline. 82 Martin Cooney, President of the PPTA, challenged this perception; he criticised Catholic schooling authorities for deliberately representing the education they provided as "a values education, and implying that such education was currently unavailable in the State system".83 Teachers in state schools, Cooney concluded, were offended by this suggestion. ${ }^{84}$ But he reluctantly conceded that in some localities - poorer areas of Christchurch, Porirua and especially South Auckland parents were choosing to send their children to Catholic schools because they regarded them as superior to their state equivalents. ${ }^{85}$

\section{THE RISING POPULARITY OF INTEGRATED SCHOOLS}

To the frequent consternation of opponents of integrated schooling, the popularity of these institutions has increased discernibly throughout the 1990s. A variety of responses to their changing fortunes have been recorded. Predictably, commentators associated with state schools have tended to be critical of suggestions that integrated schools be allowed to expand. John Letts, principal of Logan Park High School in Dunedin, for example, remarked in 1995 that "by putting money into allowing integrated schools to expand, other schools may suffer".86 Two years earlier the retiring principal of Aotea College in Wellington, Graeme Murray, had recommended that Lockwood Smith "use schools that are already there or to send their students to the state schools, many of which are substantially less than full", in preference to giving additional funding to integrated schools. ${ }^{87}$ More recently, Kevin Bunker, the PPTA General Secretary, declared that "government has a duty to support, fund and advance the State education system for all, not undermine it".88 By 'undermine', Bunker meant presumably for government not to continue granting further financial aid to integrated (and independent) schools. 
Those who advocate 'diversity' within the New Zealand schooling system argue, instead, that the provision and expansion of integrated schooling is necessary in a society professing to be a democracy. They also claim that increased funding should reflect schools' popularity. Patrick Lynch, the Executive Director of the Catholic Education Office, for instance, has claimed that considerable pressure for children to gain access to Catholic integrated schools has come from non Catholic parents "[who] were attracted by the schools' values education".89 These schools, in Lynch's opinion, "valued the opportunity to share Christian values".90 He was also confident that "the broadening of backgrounds and experiences [that accompanied this process] would be healthy for all concerned."91 The Prime Minister, Jim Bolger, was clearly supportive of such a development. Integrated Catholic school enrolments, moreover, had been increasing at a rate sufficient to prompt him to suggest greater government funding for these institutions. In Bolger's opinion, these schools were well placed to "promote new initiatives in education and deliver better outcomes for our children".92

The values that Lynch consistently thought worthy of special emphasis were those of honesty, respect, fairness, caring, non sexism and non racism ${ }^{93}$ ("solid human values"94), alongside addressing "the spiritual and cultural needs of young people".95 He hinted at the invaluable contribution that Catholic integrated schools could make to society, in the following statement.

For many youngsters their education experiences have not adequately fashioned the fundamental spiritual wellsprings of their humanity... Today, however, parents are calling for the overt teaching of fundamental literacy, numeracy and values in programmes which meet the needs of each student. ${ }^{96}$

\section{INDEPENDENT SCHOOLS: THE COST OF DIVERSITY}

Independent schooling authorities, however, were not prepared to let integrated school spokespersons claim the moral high ground over the teaching of values or providing real diversity in schooling. The Executive Director of the Independent Schools Council, Jan Kerr, has maintained that "the philosophy of education, the individual attention given to each child, and the values of the family" marked the institutions under her administration apart from state and state integrated schools. ${ }^{97}$ Nevertheless, she acknowledges that independent schools are struggling to survive in a vigorously competitive schooling environment within which several of them have chosen to "integrate for more money".98 Indeed, thirty schools have done so between 1990 and $1995 .{ }^{99}$ Kerr observed, "if it is a choice of closing down or integrating, then [private] schools will integrate".100 Two years later little improvement was apparent, Kerr having reported that:

the independent system...is still very much in survival mode...[because] the differences between state and independent schools are narrowing... every school is going to have to get behind and reinforce the differences an independent education provides. ${ }^{101}$ 
Kerr was forced to conclude that without increases in government funding, more private school proprietors would be tempted to integrate. If the entire corpus of independent schools was integrated into the state system in 1998 the cost was calculated at 100 million dollars annually. According to Kerr, the result would be that, apart from costing taxpayers more money, 102 private schools would "become less flexible and more accountable to government." 103 Her personal preference was non integration, because the perceived market appeal of private schools lay allegedly in their independence. 104 "Providing choice and diversity" was the catchcry of the independent schooling movement, but the clear expectation was that this "desirable and valuable diversity" would continue to be funded by government. ${ }^{105}$

There is some evidence to suggest that the Independent Schools Council wishes to argue that 'diversity' is synonymous with better examination performance for private schools than competing state and state integrated schools. Mark Harrison, an economist from the Australian National University, for example, has recently concluded that intense competition between New Zealand schools meant that "standards remain high". 106 But does this mean that integrated schools outperform state integrated and 'regular' state schools? Notwithstanding frequent reference to the distinguished academic records of private schools by their supporters, Cate Brett and Jenny Chamberlain's comprehensive study of New Zealand state and private schools reveals that "prestigious state schools regularly outrank private schools". 107 They conclude that "there is very little academically to distinguish top state schools from private schools". 108

Such comparisons between schools have not ignored integrated schools, although debate over their academic performance has been publicly recorded less often. Marshall Gass, an enthusiastic integrated school supporter, is a recent exception. Gass stated unreservedly that in "competing in the marketplace with their end product - the students", these institutions have performed better in public examinations than their state school counterparts. ${ }^{109}$ A reply was soon forthcoming. Warren Seastrand, the principal of Glenfield College in Auckland, responded by referring to unspecified research measuring successful study at university, which showed that co-educational state schools outperformed integrated, independent, and single sex schools. ${ }^{110}$

\section{A MARKET MODEL FOR INTEGRATED SCHOOLS}

Discussion about integrated schools in the 1990s, we suggest, has tended to concentrate on their philosophy and place within the New Zealand schooling system rather than their academic merits. Such discussion, not surprisingly, is useful for revealing underlying assumptions about choice and markets in education, within the context of a neo-liberal society. This was readily apparent in the case of advice given two years ago by a senior Ministry of Education official, John Gill, to the former Secretary for Education, Maris O'Rourke, regarding integrated schools. Gill recommended that the Ministry adopt a market approach to these schools. If the school proprietors could produce "market research proving [that] demand exists" for integrated schooling, and calculated their projected roll growth alongside their existing market standing, then Gill suggested that the 
Ministry "not undermine the expansion aspirations of the proprietors of integrated schools". 111

The Minister of Education (Wyatt Creech) must have acted on this advice, given that an additional six million dollars of suspensory loan money was allocated to integrated school proprietors in the 1997 budget, to cover the cost of providing more classrooms in schools experiencing enrolment pressures. ${ }^{112}$ Furthermore, Creech was sympathetic to the plight of crowded Catholic integrated schools whose governing authorities sought to raise the five percent enrolment restriction for non Catholic pupils to ten percent, to ease long waiting lists. The five percent requirement had operated from 1975 until the Minister agreed to consider applications for an increase on a case by case basis in 1996. Pat Lynch's response, on behalf of Catholic integrated schools, was that "this [policy] will help the state cope with basic growth".113

The granting of any extra funding to Catholic integrated schools remained clearly problematic in the eyes of state schooling representatives. Upon hearing of the government's intention late in 1996 to give 373 million dollars to fund the expansion of integrated schools for the period 1996-2006, Martin Cooney complained that "backroom deals between the government and the Catholic church ... [are] entirely inappropriate".114 A PPTA Executive Committee member, David Freyne, echoed a similar sentiment the following year. Critical of the secrecy surrounding decisions regarding integrated school funding in the 1997 budget, Freyne wrote:

PPTA insists that any reviewed arrangements should be made with full and open debate. No private deal with a sector of our nation's community should be contemplated. Any arrangement with the proprietors that is not out in the open would offend the sense of justice that we value in this country. ${ }^{115}$

One year on, the NZ Catholic publication reported that ongoing discussions between Pat Lynch and the government continue to focus on "the future of the Catholic school system". Lynch allegedly informed Catholic bishops and school proprietors on 1 July 1998 about "a whole new important package to bring about future self-sustainability of Catholic integrated schools".116 What this 'package' might contain, though, has not been specified to date.

Nevertheless, both Freyne and Cooney understood from the Minister and Ministry's viewpoint that it was far cheaper to fund roll increases in Catholic schools than to accommodate up to possibly 80,000 additional school age children in new schools by the year 2010.117 Catholic schooling authorities, for their part, predicted a 35 per cent increase in enrolments at their institutions up to 2010 also. 118 In short, the rapidly expanding school age population - projected to peak in 2010-2011 - had obvious implications for Catholic schools, whose authorities expected to attract an increasing proportion of these enrolments. Two years ago the newly appointed Secretary for Education, Howard Fancy, reported that by 2006, 6,000 extra classrooms and 54 new schools would be needed to accommodate pupils. Over half of these buildings were destined for Auckland.119

In his capacity as the Catholic schools' spokesperson, Pat Lynch has consistently maintained that future roll increases in integrated Catholic schools are 
unavoidable. Rejecting Cooney's suggestion that ghetto schools will become increasingly visible in several New Zealand communities if government continues to support the expansion of Catholic schools, ${ }^{120}$ Lynch has argued:

Rolls are rising as more Catholic parents, many of them poor, seek a Catholic education for their children ... We are simply talking about the Catholic system keeping its basic market share at a time of great growth in secondary rolls. ${ }^{121}$

\section{MARKETS, SCHOOLS AND CHOICE}

Lynch's assessment of events has been challenged on two broad fronts. With respect to the consequences of government support for integrated schools, one newspaper editor has predicted that many state schools will shrink and "latent divisions in society [will] be emphasised further".122 It was thought such 'divisions' would prevent pupils from different backgrounds from mixing with one another. Moreover, the editor reported that the popularity of Catholic schools ought not to be attributed to an increasing demand for access to a "Catholic education" per se, contrary to Lynch's assertions. Instead, non Catholic pupils were attending integrated Catholic schools for reasons other than access to religious instruction:

What has been happening in some areas is that parents want their children to go to Catholic schools, not because of their 'special character' and religious education, but because they think they are better than the nearby state schools ... Any church connections are often irrelevant as far as many parents are concerned. 123

The second challenge essentially concerns broader academic and popular debate over markets and parental choice. Some commentators have declared that the growing popularity of integrated schools in the 1990s is merely a reflection of greater official advocacy for parental choice of schooling. Roger Kerr, the Executive Director of the New Zealand Business Roundtable, in the process of advocating greater competition between schools, for example, wrote approvingly of "the international trend [being] towards greater choice in education".124 A long time proponent of 'choice', Ruth Richardson (now a member of the ACT political party), is similarly convinced that "genuine choice [leads to] performance, whether it is for railways or education". 125

But the question should be asked: who does the choosing - parents or schools? Mark Harrison is adamant that the decision currently rests with parents, who tend to seek detailed information about independent schooling options for their children. "Parents perform a cost-benefit analysis before committing themselves", he concludes. ${ }^{126}$ Informed parental choice may be something of a fiction, though, according to Ivan Snook.127 Referring to an OECD examiners' report on the choice policies evident in the education systems of ten countries, Snook wrote that "studies show that parents and children rarely choose schools on the basis of well-informed comparisons of education policy". 128 Choice, as Cathy Wylie of the New Zealand Council for Educational Research prefers to describe it, 
"is not a simple, cheap or efficient option". It has, and will continue to have, farreaching consequences for several New Zealand schools, notably those seen to be poor performers or second class institutions. ${ }^{129}$

Martin Thrupp, echoing this sentiment, refers to an undesirable polarisation between lower socioeconomic ('sink') schools and popular, high socioeconomic ('winning') schools. The reality, he notes, is that "choice here clearly belongs to the schools, not parents". 130 .Jan Corbett's investigations reveal similar concerns to those of Wylie and Thrupp. She notes how the Tomorrow's Schools' reforms led to the parental expectation of "absolute choice" of schools being superseded by school authorities having "absolute choice ... [to] hand-pick their applicants".131 What has happened, Cate Brett and Jenny Chamberlain assert, is that

... instead of being demand driven, education has become supply driven: it is prestigious schools, in short supply, which do the choosing. Not parents. ${ }^{132}$

Such choice extends to integrated schools who often "behave like private schools", they note. These schools can exclude pupils who do not accept or conform to an institution's special character, as defined by the 1975 Integration Act. ${ }^{133}$

Debate over educational choice has another, related, dimension. In the opinion of WEB Research - commissioned by the Ministry of Education in 1997 to report on education in the mid Canterbury region - a policy of school choice does not automatically enhance the quality of education available in communities. To this end, the consultants pointedly remarked: "it can sometimes appear to the observer that the question of the quality of education is seen more as an aid to marketing than as an end in itself". 134 In a similar vein, Alvaro Marchesi, Professor of Educational Psychology at the University of Madrid, warned that a desire to adopt a market approach to schooling would lead to greater public preoccupation with examination results. This would enable schools to select pupils according to their perceived academic merit, 135 to the detriment of wider educational considerations.

Colin McGeorge's study of private and integrated schools in New Zealand appropriately subtitled "subsidising the illusion of choice"136 - affords further evidence that 'choice' is highly problematic both conceptually and practically. He notes that one purpose of post 1984 education reforms was to provide for greater choice and competition, although in real terms most parents' educational options have not been increased. Integrated (and private) schools, McGeorge concludes, "provide far less choice for parents than their organisers and supporters claim",137 mainly because whatever choice is available is exercised less often by parents than by schools. In short, the diversity among competing schools alluded to and valued by some sectors of the public has been, and continues to be, controlled by school authorities. ${ }^{138}$ Nonetheless, it is a diversity that in the case of integrated Catholic schools currently embodies 238 institutions, 56,684 pupils and 3,153 teachers. ${ }^{139}$ These pupils constitute nearly ten percent of national primary and secondary school enrolments; private schools, by comparison, account for about 3.5 percent of total school enrolments. ${ }^{140}$ 


\section{INTEGRATED SCHOOLS IN THE LATE TWENTIETH CENTURY}

There is every reason to believe that diversity in the compulsory schooling sector will remain a feature of educational life in the twenty first century. Rex Mason had given ministerial endorsement to the notion and its practice in 1945, as did Mervyn Wellington forty years later. The latter enthusiastically declared his support for "a choice of approaches to education" being available to parents and children. Accordingly, Wellington applauded the view that parents should have the right to send their sons and daughters "to schools which fitted their personal faith and philosophy". 141

Nonetheless, critics of integration continue to assert that it will continue to have serious economic and social outcomes for all New Zealand citizens. They maintain that the decision to grant full (or even partial) state aid to private schools must reside ultimately with the public, not politicians. 142 For Mulheron, an avid opponent of integration and state aid to private schools, there could be only one possible solution:

When public school communities and their teachers at the school level make their politicians and educational representatives accept that private and public schools are different in purpose and control, and that they cannot be considered equally deserving of state aid and money, they will break the hold of the state aid lobby. 143

Those who remain vehemently opposed to state aid and integration may choose to further examine the Catholic Education Office's announcement involving "planning for expansion and growth",144 as well as claims that integrated schools have not only "learned to use every single cent frugally ... [while] money was never in short supply" for state schools but also that they "have a right to the taxpayer dollar just as well as everyone else". ${ }^{145}$ Opponents still complain that private schools were given huge taxpayer handouts under the 1975 Act without adequate public consultation. 146 Accordingly, they urge the current government to "[cease] funding the expansion of Roman Catholic schools".147 The fact that 'church and state' remains bitterly contested territory in the 1990s is also apparent from Ivan Snook's question to Pat Lynch, as the national spokesperson on Catholic schools (albeit over his expressed support for education vouchers): "Is the Catholic Church preparing to sell out the state system from which it has benefited enormously?"148

The official Catholic response to current criticism of both integration and state aid has been to emphasise the financial burden under which Catholic schools labour, and to accuse their opponents of "wanting to relitigate a situation which has been agreed for a generation".149 In July 1998, Lynch revealed that Catholics have national school debts of about 80 million dollars to service which could be repaid through attendance dues set by each diocese, by 2012.150 These debts were incurred prior to integration, when suspensory loans were introduced. Lynch acknowledges that there is a price to be paid for safeguarding the all-important Catholic 'special character'. He has noted that Catholics "cannot pay for Catholic character funding [solely] with government money".151 In other words, the 
Catholic community will still be expected to provide some financial contribution to the cost of educating their children in the Catholic tradition.

\section{AN UNRESOLVED STRUGGLE}

As we approach the twenty-first century there are few, if any, indications that debate over private school funding and integration has abated subsequent to the passing of the 1975 integration legislation. Advocates of educational 'diversity' look set to continue their lobbying, conscious of the need to avoid becoming what one private school headmaster referred to 30 years ago as "pale imitations of the State schools" - institutions that have abandoned "their burning conviction and freedom".152 Critics of New Right education policies and practices, by comparison, appear likely to stay resolutely opposed to politicians granting more money to both integrated and independent schools. They believe that such a practice simply undermines public schools, fosters "religious or philosophical indoctrination", and facilitates "the downgrading and dismantling of the public education system". 153

In 1975, it will be recalled, Sir Roy Jack warned Parliament that the integration legislation was "full of fish hooks and broken glass".154 Subsequent events have supported this assessment, while at the same time suggesting that, contrary to the Currie Commission's opinion, ${ }^{155}$ debate over state aid to private schools (and, later, integration) is unlikely to ever be resolved within, or confined to, the political domain. As Mulheron noted, state aid to church schools and integrated schooling look set to remain "big political, financial and educational matters" in New Zealand society. 156

\section{REFERENCES}

1. J.C. Dakin, Education in New Zealand, Auckland: Leonard Fullerton, 1973, p.84.

2. J. Mackey, The Making of a State Education System: The Passing of the New Zealand Education Act, 1877, London: Geoffrey Chapman, 1967, pp. 262-265.

3. The Private Schools Conditional Integration Act, 1975, No. 129, in The Statutes of New Zealand: 1975, Wellington: Government Printer, 1976, pp. 1122-1171. Forty five politicians voted in favour of the Bill, while 31 opposed its introduction. See New Zealand Parliamentary Debates (NZPD), Vol. 402, 1975, p.5220 (7 October).

4. M. Wellington, New Zealand Education in Crisis, Auckland: Endeavour Press, 1985, pp.78-79.

5. R. Openshaw, G. Lee and H. Lee, Challenging the Myths: Rethinking New Zealand's Educational History, Palmerston North: Dunmore Press, 1993, pp.8284.

6. Ibid., p.242.

7. Ibid.

8. I.A. McLaren, Education in a Small Democracy: New Zealand, London: Routledge and Kegan Paul, 1974, pp.58-60: R. Openshaw et al., op. cit., pp.242-243.

9. I.A. McLaren, ibid., p.58; NZPD, Vol. 24, 1877, p.36 (24 July). 
10. National Education, Vol. 1, No. 2, 1919, p.32 (15 March).

11. NZPD, Vol. 114, 1900, p.469 (2 October).

12. Ibid.

13. R. Openshaw et al., op. cit., p.243.

14. I.A. McLaren, op. cit., p.58: R. Openshaw et al., op. cit., p.176.

15. H.G.R. Mason, Education Today and Tomorrow, Wellington: Government Printer, 1945, p.93.

16. Ibid., p.70.

17. Ibid.

18. NZEI, Religious Instruction in Schools: The Viewpoint of the Primary Teachers, Wellington: NZEI and G. Deslandes, 1944, p.50.

19. Ibid., p.53.

20. Ibid., p.50.

21. Ibid., pp.50-51.

22. I.A. McLaren "Education", in I. Wards (ed.), Thirteen Facets: Essays to celebrate the Silver Jubilee of Queen Elizabeth the Second, 1952-1977, Wellington: Government Printer, 1978, p.219; R. Openshaw et al., op. cit., pp.242-243.

23. N.H. Gascoigne, "An Address to the Caucus of the Labour Party on the Question of State Aid to the Private Schools", 23 September 1948 (unpublished paper).

24. H. Mason, op. cit., p.70.

25. N. Gascoigne, op. cit.

26. I.A. McLaren, Education in a Small Democracy, op. cit., p.59; R. Openshaw et al., op. cit., p.243.

27. I.A. McLaren, ibid.

28. Appendices to the Journal of the House of Representatives (AJHR), E-1, 1957, pp.47-48.

29. C.L. Bailey, "Evidence Submitted to the Education Committee of the House of Representatives on the matter of State Aid to Non-State Schools", September 1956 (unpublished paper).

30. Ibid.

31. Ibid.

32. NZPD, Vol. 310, 1956, pp.2724-2746 (24 October); AJHR, E-1, 1957, pp.47-48.

33. AJHR, ibid., I. McLaren, Education in a Small Democracy, op. cit., pp.60-61.

34. Report of the Commission on Education in New Zealand, Wellington: Government Printer, 1962, p.1 (Chair: G. Currie).

35. Ibid., pp.8, 698.

36. Ibid., p.716.

37. I.A. McLaren, Education in a Small Democracy, op. cit., p. 62.

38. I.A. McLaren, "Education", op. cit., p.219; R. Openshaw et al., op. cit., p.244.

39. I.A. McLaren, Education in a Small Democracy, op. cit., p.63; J. Mulheron, State Aid, Integration and New Zealand's Public Schools, Wellington: Paerangi Books, 1987, pp. 10-11. Catholic education interests were conveyed through the Catholic Educational Council for New Zealand. 
40. E. Isichei, "Christianity: Catholics since the 1960s", in P. Donovan (ed.), Religions of New Zealanders, Palmerston North: Dunmore Press, 1990, p.73; M. King, God's Farthest Outpost: A History of Catholics in New Zealand, Auckland: Viking, 1997, pp.177, 179; I. McLaren, "Education", op. cit., p.220. Vatican II involved four convocations held in Rome for Catholic bishops between October 1962 and December 1965. Five documents from the convocations were released between 1963 and 1965. These were to profoundly affect the policies and practices of the Roman Catholic church post 1965.

41. AJHR, E-1, 1964, p.8; J. Mulheron, op. cit., p.11; R Openshaw et al., op. cit., p.244. The Leader of the Labour party, Arnold Nordmeyer, also agreed with the stance adopted by the ICIS.

42. I.A. McLaren, Education in a Small Democracy, op. cit., p.62.

43. H. Bodey, Religion, London: B.T. Batsford, 1973, p.89; A. Davidson, 'Catholic dimensions', New Zealand Education Review, Vol. 2, No. 19, 1997, p.31 (10 September).

44. I.A. McLaren, "Education", op. cit.

45. I.A. McLaren, Education in a Small Democracy, op. cit., p.63; I. McLaren, Education, op. cit., p.221.

46. J. Mulheron, op. cit., R. Openshaw et. al., op. cit. p.245.

47. New Zealand Labour Party Election Manifesto, Wellington: Standard Press, 1972, p.10.

48. K. Sinclair, Halfway Round the Harbour: An Autobiography, Auckland: Penguin Books, 1993, p.201.

49. Ibid.

50. Ibid. It should be noted that the state aid Sinclair alluded to was not to be restricted to primary schools.

51. Ibid., p.11. See also P. Lynch, "Integrated schools", Eduvac, Vol. 4, No. 193, 1994 , p.2 (31 October). Lynch reports that Norman Kirk wanted to solve "the one hundred year running sore" over the funding of private schools.

52. I.A. McLaren, Education in a Small Democracy, op. cit., p.64; J. Mulheron, op. cit., pp.10-11. The Integration Working Party included a Catholic delegation of six people and four state schooling representatives.

53. I.A. McLaren, "Education", op. cit., p.221; J. Mulheron, op. cit., p.12.

54. I.A. McLaren, Education in a Small Democracy, op. cit.

55. Ibid.

56. J. Marshall and A. Hoff, "The Integration Act and Religious Indoctrination", New Zealand Journal of Educational Studies (NZJES), Vol. 19, No. 2, 1984, pp.124-135; J. Mulheron, op.cit., pp.11-23; R. Openshaw et al., op. cit., pp.245250: I. Snook, "Moral Education: Past, Present, and Future", in P.D.K. Ramsay (ed.), Curriculum Issues in New Zealand, Year Book of Education No. 8, Wellington: NZEI, 1980, pp.212-214.

57. I. Snook, ibid., p.213.

58. NZPD, Vol. 402, 1975, p.5213 (7 October).

59. The Private Schools Conditional Integration Act, 1975, Sections 2-3, pp. 11241125, op.cit.; J. Mulheron, op.cit., pp.4-5; M. Wellington, op. cit., pp. 78-86.

60. Kavanagh College, Dunedin: Ipsa Duce, Dunedin: no publisher or date given (circa 1989), p.4. 
61. P. Stirling, "Getting together on the Act", New Zealand Listener, 24 October 1981, p.24.

62. Ibid., pp.23-24.

63. C. McGeorge and I. Snook, Church, State, and New Zealand Education, Wellington: Price Milburn, 1981, p.55; J. Mulheron, op.cit., p.4; P. Stirling, ibid., p.24.

64. J. Mulheron, ibid., P Stirling, ibid.

65. M. Wellington, op.cit., p.78.

66. New Zealand Listener, 9 October 1982, p.24. Article titled "The schools integration issue".

67. R. Openshaw et al., op.cit., p.248.

68. Otago Daily Times, 16 June 1984, p.18. Article titled "Upgrading dates deferred for Catholic schools".

69. Otago Daily Times, 14 August 1986, p.1 (Article titled "25 years for loans"); Otago Daily Times, 21 May 1987 (Article titled "School works funding altered"); Dunedin Star Midweek, 3 June 1987, p.1 (Article titled "New school in central city").

70. Concern had been expressed to the Integration Standing Committees of the two Integration Conferences (held on 8 March 1985 and 1 May 1986), that "particular issues concerning building" ought to be studied as well as staffing and enrolment matters. Yet the Briefing Papers of the Department of Education given to Russell Marshall stated that "no difficulties are envisaged" regarding integrated schooling policy. Refer to Comments on Labour Party 1984 Education Policy, updated to show the position as at 1 August 1986, Wellington: Department of Education, 1986, pp.43-44.

71. The New Nation: The New Zealand Labour Party Newspaper, Wanganui: The Wanganui Chronicle, 1984, p.4.

72. Otago Daily Times, 14 August 1986, p.1.

73. The Press, 30 April 1986. Article titled "Catholic schools accepted burden".

74. R. Openshaw et al., op. cit., pp.250-251.

75. Otago Daily Times, 4 June 1987 (Article titled "School funding policy"); A.Morrison, "Market culture", Dominion Sunday Times, 19 July 1987, p.11.

76. Report of the Taskforce to Review Education Administration, Administering for Excellence: Effective Administration in Education, Wellington: Government Printer, 1988, p.4 (Chair: B. Picot). The theme of promoting 'efficiency through choice' has dominated education reports and commentaries in New Zealand since the late 1980s. A provincial newspaper, for example, chose the following heading for an editorial in 1994: "School choice vital to maintain standards". Such headings now appear frequently in the New Zealand press. See the Waikato Times, 11 March 1994, p.6.

77. L. Smith, Education Policy: Investing in People - Our Greatest Asset, Wellington: Government Printer, 1991, p. 46.

78. T. Murphy, "Government to discourage school integration", New Zealand Herald, 25 February 1991; Waikato Times, 23 March 1991 (Article titled "Teacher union reaction 'derogatory'"); The Review of Integration Policy (no publisher given), July 1991, pp.3-6.

79. L. Smith, op.cit., p.8. 
80. Otago Daily Times, 30 October 1991. Article titled "Increased private school subsidy urged".

81. Waikato Times, 21 March 1991. Article titled "NZEI accuses Minister of partiality".

82. Waikato Times, 21 June 1996, p.6 (Article titled "Public or private - the education dilemma"); Ibid., 21 September 1996; New Zealand Herald, 30 September 1996, A5 (Article titled "Catholic school growth slated").

83. New Zealand Herald, 13 June 1996, A5; Eduvac, Vol. 6, No. 272, 1996, p.3 (7 October). Article titled "Teachers voice concern at Catholic schools expansion".

84. Ibid.

85. A. Ots, "Trouble brews as Catholic rolls rise", Evening Post, 27 November 1996.

86. R. Brown, "State schools fear integrated success", Otago Daily Times, 3 November 1995.

87. Otago Daily Times, 20 December 1993. Article titled "Planned integration of Hutt school criticised".

88. K. Bunker, "Kite-flying", Eduvac, Vol. 8, No. 315, 1997, p.2 (28 October).

89. A. Hotere, "Unholy Integration", New Zealand Education Review, Vol. 2, No. 10, 1997, p.4 (9 July). See also Eduvac, 7 October 1996, op.cit; P. Lynch, "Catholic Schools", Eduvac, Vol. 6, No. 273, 1996, p.2 (14 October).

90. Ibid.

91. Ibid.

92. New Zealand Education Review, Vol. 2, No. 25, 1997, p.2 (October). Article titled "PM's suggestions classist". See also New Zealand Herald, 13 June 1996, A5.

93. Eduvac, Vol. 9, No. 332, 1998, p.2 (30 March). Article titled "Schools told to teach basic values".

94. P. Lynch, "Support change makers", Eduvac, Vol. 9, No. 325, 1998, p.2 (9 February).

95. P. Lynch, "Improving the school system", Northern Advocate, 13 November 1996.

96. Ibid.

97. J. Kerr, "More choice in education", Eduvac, Vol. 8, No. 304, 1997, p.2 (28 July). See also Independent Schools Council, "Focus on ... A civic society", Wellington: ISC, June 1997, pp.1-2.

98. J. Rivers, "Independent school sector is shrinking", New Zealand Education Review, Vol. 1, No. 1, 1996, p.4 (8 May).

99. J. Kerr, "Education as an art form", Eduvac, Vol. 5, No. 218, 1995, p.4 (26 June).

100. J. Rivers, op.cit. See also J. Kerr, "Innovative approaches", Eduvac, Vol. 8, No. 291, 1997, p.2 (24 March).

101. A. Fyfe, "Independents struggle", New Zealand Education Review, Vol. 3, No. 3, 1998, p.1 (20 May).

102. J. Kerr, "Government has duty to fund", Eduvac, Vol. 8, No. 316, 1997, p.2 (3 November).

103. A. Fyfe, op.cit.

104. J. Rivers, op.cit. 
105. J. Kerr, "Government has duty to fund", op.cit. Refer also to Otago Daily Times, 4 November 1995 (Article titled "Education Minister suggests setting schools free - Smith wants more parental choice"); Waikato Times, 4 November 1995, p.2 (Article titled "Smith suggests state cash for private schools"); Otago Daily Times, 10 November 1995, p.6 (Editorial: "Education freedom"); Independent Schools Council, "Focus on ... Why choice is essential", Wellington: ISC, March 1994, pp.1-2; Independent Schools Council, "Focus on ... Innovation", Wellington: ISC, March 1997, pp.1-2.

106. Eduvac, Vol. 9, No. 339, 1998, p.5 (2 June). Article titled "Schools' accountability raised at ISC conference". See also Otago Daily Times, 16 February 1998. Article titled "Cost of an exclusive education rises by up to $20 \%$ - survey".

107. C. Brett and J. Chamberlain, "Where to go: private or state?", North and South, Vol. 145, 1998, p.37 (April).

108. Ibid., p.45.

109. M.E. Gass, "Spread the education dollar", Eduvac, Vol. 8, No. 317, 1997, p.2 (10 November ).

110. W. Seastrand, "Looking at school results", Eduvac, Vol. 8, No. 319, 1997, p.2 (24 November). See also D. Matheson, "State schools beat private", New Zealand Education Review, Vol. 1, No. 16, 1996, pp.1-2 (16 August).

111. J. Gill, Schooling for the Future, Wellington: Ministry of Education, 1996, p.14.

112. P. Lynch, "Budget ' 97 offers much to education", Eduvac, Vol. 8, No. 304, 1997, p.2 (28 July).

113. A. Hotere, op.cit. Refer also to Eduvac, 7 October 1996, op.cit., Eduvac, 7 October 1996, op.cit., p.5. Article titled "Catholic schools convention attracts hundreds".

114. New Zealand Herald, 30 September 1996, A5. Article titled "Catholic school growth slated".

115. D. Freyne, "Why a budget review of integrated schools?", PPTA News, Vol. 18, No. 7, 1997, p.2 (July).

116. NZ Catholic, No. 44, 1998, p.1 (12 July).

117. A. Ots, op.cit.

118. Ibid. See also New Zealand Herald, 30 September 1996, A5.

119. W. Gamble, "Plenty of free advice for education head as he faces challenge of growing school rolls", New Zealand Herald, 26 July 1996. See also Waikato Times, 17 August 1996 (Article titled "Rising school rolls worry minister"); L. Quaintance, "No new high schools until 2000", New Zealand Herald, 23 November 1996; New Zealand Herald, 17 March 1998, A12 (Editorial: "Blow to quality education").

120. New Zealand Herald, 30 September 1996, A5.

121. A. Ots, op.cit. See also Eduvac, Vol. 6, No. 258, 1996, p.2 (10 June). Article titled "Catholic schools a great treasure: Pat Lynch". Lynch noted that "our Catholic schools are on a roll", once again because of rapidly expanding enrolments. Two years earlier, he reported that Catholic schools were no longer in "maintenance mode"; they now had "a wonderful opportunity to expand their market share". See Eduvac, Vol. 4, No. 177, 1994, p.2 (13 June). Article titled "Catholic eye more new schools".

122. Otago Daily Times, 4 October 1996, p.6 (Editorial: "Integrated Schools"). 
123. Ibid.

124. New Zealand Education Review, Vol. 2, No. 21, 1997, p.6 (24 September). Article titled "Problems not hard to define". Kerr was giving an address to the Institute of Personnel Management in Auckland.

125. Eduvac, Vol. 9, No. 334, 1998, p.3 (27 April). Article titled "Former finance minister wants schools privatised to introduce competition". See also A. Hotere, "Attending to schools' private functions", New Zealand Education Review, Vol. 2, No. 43, 1998, p.9 (25 March).

126. Eduvac, Vol. 9, No. 339, 1998, p.5 (2 June).

127. NZEI Rourou, Vol. 7, No. 1, 1996, p.3 (9 February). Article titled "Vouchers again?".

128. I. Snook, "Option for the rich", Eduvac, Vol. 6, No. 251, 1996, p.2 (22 April).

129. C.Wylie, "Now we know", New Zealand Education Review, Vol. 3, No. 2, 1998, p.8 (13 May).

130. M. Thrupp, "Shameful legacy", New Zealand Education Review, Vol. 3, No. 2, 1998, p.10 (13 May).

131. J. Corbett, "Is education making the grade?", The Independent, 23 August 1996, p.27.

132. C. Brett and J. Chamberlain, op.cit., p.36.

133. Ibid, p.37.

134. F. Cassie, "Parental choice sows seeds of uncertainty", New Zealand Education Review, Vol. 2, No. 11, 1997, p.7 (16 July).

135. F. Cassie, "Keynote conference speaker advocates pluralist school system", New Zealand Education Review, Vol. 2, No. 36, 1998, p.2 (4 February).

136. C. McGeorge, "Private and integrated schools in New Zealand: subsidising the illusion of choice", Journal of Education Policy, Vol. 10, No. 3, 1995, p.259.

137. Ibid.

138. Ibid., p.269.

139. Eduvac, Vol. 9, No. 337, 1998, p.2 (18 May). Article titled "National Catholic Schools' Day celebrated in NZ".

140. Catholic Diocese of Hamilton, "A Teaching Career in a Catholic Integrated School" (unpublished brochure), March 1997, p.1; J. Gill, op.cit., p.14. Brett and Chamberlain note that the total enrolment in New Zealand state integrated schools is presently 68,118 pupils. These pupils attend Anglican, Presbyterian, Seventh Day Adventist, Steiner, Methodist, Hare Krishna, and Interdenominational Christian schools. Catholic schools currently account for 83.2 per cent of national integrated school enrolments. See C. Brett and J. Chamberlain, op.cit., p.37; C. McGeorge, op.cit., p.263; Ministry of Education, Education in New Zealand, 1997, Wellington: Ministry of Education, 1997.

141. M. Wellington, op.cit., p.86.

142. A.Ots, op.cit.; Otago Daily Times, 4 October 1996, p.6; PPTA News, Vol. 18, No. 7, 1997, p.2 (July); K. Bunker, op.cit.; J. Minto, "Grotesque failure", Eduvac, Vol. 6, No. 272, 1996, p.2 (7 October); Eduvac, 7 October 1996, op.cit.; J. Minto, "Free market ideology", Eduvac, Vol. 6, No. 275, 1996, p.2 (29 October).

143. J.Mulheron, op.cit., p.22.

144. Eduvac, 18 May 1998, op.cit.

145. Eduvac, 10 November 1997, op.cit. 
146. Eduvac, 29 October 1996, op.cit.; P Raffills, "Quality education", Eduvac, Vol. 6, No. 280, 1996, p.2 (2 December); J Mulheron, op.cit., p.12.

147. Otago Daily Times, 4 October 1996, op.cit.; Eduvac, 7 October 1996, op.cit.

148. I. Snook, "Option for the Rich", Eduvac, Vol. 6, No. 251, 1996, p.2 (22 April).

149. New Zealand Herald, 30 September 1996, op.cit.; A. Ots, op.cit. See also Eduvac, 31 October 1994, p.2, op.cit.

150. D. Coup, "How much parents pay in school fees depends on the diocese", NZ Catholic, No. 44, 1998, p.15 (12 July).

151. Ibid.

152. H.R. Hornsby, "The independent schools of New Zealand", in F.W. Mitchell (ed.), New Zealand Education Today, Wellington: A.H. and A.W. Reed, 1968, p.111.

153. J.Mulheron, "To the Boards of Trustees of all New Zealand's Public Schools", August 1989, p.1 (SPPE Secretary's newsletter to Boards of Trustees).

154. NZPD, Vol. 402, 1975, p.5213 (7 October).

155. Report of the Commission on Education in New Zealand, op.cit., p.8.

156. J. Mulheron, State Aid, Integration and New Zealand's Public Schools, op.cit., p.12. 